\title{
Perceptions towards Distributed Leadership in School Improvement
}

\author{
Firas Jalal Shakir (Corresponding author) \\ School of Housing, Building and Planning, Universiti Sains Malaysia \\ 3B-24-07 N-Park Condominium, Jalan Batu Uban \\ 11700, Gelugor, Pulau Pinang, Malaysia \\ Tel: 60-17-368-4129 E-mail: hjijo@hotmail.com \\ Jinan Hatem Issa \\ School of Educational Studies, Universiti Sains Malaysia \\ 3B-24-07 N-Park Condominium, Jalan Batu Uban \\ 11700, Gelugor, Pulau Pinang, Malaysia \\ Tel: 60-17-368-4125Ｅ-mail: jinanfiras@hotmail.my \\ Paiman Omer Mustafa \\ School of Educational Studies, Universiti Sains Malaysia \\ 11800 USM, Pulau Pinang, Malaysia \\ E-mail: paimanom@yahoo.com
}

Received: April 7, $2011 \quad$ Accepted: May 3, $2011 \quad$ Published: October 1, 2011

doi:10.5539/ijbm.v6n10p256 URL: http://dx.doi.org/10.5539/ijbm.v6n10p256

The research is facilitated and supported by Universiti Sains Malaysia (USM)

\begin{abstract}
In spite of the sizable growth in the number of empirical studies tackledthe distributed form of leadership over the past decade, the bulk of this research isa case study. Relatively few published studies have investigated the impact of distributed leadership on school improvement; therefore, the current paper attempts to investigate TESOL teachers'perceptions towards distributed leadership and school improvement. The theoretical framework for this study is grounded on the multifactor transformational/transactional leadership model (Bass, 1985, 1990; Bass \& Avolio, 2000). Two TESOL teachers from two different schools, in Pulau Penang, were interviewed regarding this phenomenon, which is still in its infancy stage. The study encourages a distributed leadership perspectivethat assists in building the academic capacity of schools as a means of improvement. Besides, it argues that the distributed perspective proposes an important theoretical lens through which leadership practiceswithin a school can be reconfigured and reconceptualised.The findingsshow that there are two different applied forms of leadership in the two schools. On the one hand, the first interviewee reveals her approving perceptions towards the distributed form of leadership as she praises the principal's characteristics, whilst the second interviewee, on the other hand, expresses her disapproving perceptions towards the control form of leadership through criticising the current principal's characteristics. A further finding exposes that the prevailingdistributed form of leadership does contribute to the school improvement. On the contrary, the current control form of leadership in the other school produces school's deterioration.
\end{abstract}

Keywords: Distributed leadership, Teachers' perceptions, Top-down, Bottom-up, Control form of leadership, School improvement

\section{Introduction}

The modern educational reforms, which have occurred recently, set a tremendous premium upon the relationship between leadership and school improvement. In fact, the magnitude of leadership in securing and sustaining 
improvement has been constantly emphasised by several international research evidences (Harris, 2004; Hopkins, 2001; West, Jackson, Harris, \& Hopkins, 2000). The overarching message about leadership is one of building the school'scommunity in its ample sensethrough developing and engaging others (Harris \& Chapman, 2002). The burden of accountability pressures requiring a rapid change falls on the principalto make it happen(Protheroe, 2005).Obviously, effective leaders play an indirect but authoritative influence on the effectiveness of the school and the accomplishments of students (Leithwood \& Jantzi, 2000). A well-known researcher lately concludes, 'It has become increasingly clear that leadership at all levels of the system is the key lever for reform, especially leaders who a) focus on capacity building and b) develop other leaders who can carry on'(Fullan, 2006).

The term 'Distributed leadership' is the recent trend in leadership and school improvement. Furthermore, it is receiving much attention and growing empirical support (Gronn, 2000; Harris, 2004; Harris\&Chapman, 2002; Heck\&Hallinger, 2009; Hopkins\&Jackson, 2002; Spillane, Halverson, \&Diamond, 2001).Two alterations in the perspectives of educational researchers and policy makers have been revealed by previous research findings. First, there is an increased curiosity in how leadership is shared or 'distributed' among administrators, teachers, and parents in schools (Gronn, 2002; Leithwood, Mascall, \& Strauss, 2009; Spillane, 2006). Scholars now advocate that distributed leadership could offer a more sustainable means of building the type of learning-focused climate that distinguishes high-performing schools (Day, Gronn, \&Salas, 2006; Leithwood, Louis, Anderson, \&Wahlsttom, 2004; Spillane, 2006). Second, the on-goingfocused curiosity in the crucial leadership role that plays in school improvement (Leithwood et al., 2004; Luyten, Visscher, \& Witziers, 2005; Reynolds, Teddlie, Hopkins, \& Stringfield, 2000; Sleegers, Geijsel, \&Van den Berg, 2002). Previous research has not effectivelytackled the modelling of change in leadership and related educational processes (Heck\&Hallinger, 2005; Krüger, Witziers, \&Sleegers, 2007).

In spite of thecalls for studies that examine policy prescriptions for shared leadership against empirical evidence, most studies have been descriptive rather than analytical (Heck\&Hallinger, 2005; Leithwood et al., 2009), whereas the current study attempts to inspect distributed leadership and school improvement in depth through seeking the answers to two questions: firstly, what are the teachers' perceptions of the type of distributed form of leadership applied in their schools and secondly, whether the existing type of leadership contributes to school improvement.

\section{Related Literature}

To secure and sustain school improvement, effective distributed leadership is generally demanded(TSE, 2006).Distributed leadership is defined as one of the forms of leadership that involves all the different forms of collaboration experienced by the principal, teachers, and members of the school's improvement team in leading the school's development (Heck \& Hallinger, 2009).Fullan (2001)states that the notion of sustainable change in schools is based on distributed leadership among the school staff. Hence, distributed leadership must bring about changes that are embraced and possessed by the teachers who are in charge ofimplementing those changes in classrooms (Fullan, 2006; Hall\&Hord, 2001; Heck\&Hallinger, 2009). In the same vein, Harris (2004) and with Muijs (2005) assert that distributed leadership focuses on employing expertise wherever it exists within the organisation rather than searching this via formal position or role.Moreover, distributed leadership is characterised as one of the collective leadership forms in which teachers develop expertise by working together as contrary to traditional concepts of leadership, which arebased upon an individual managing hierarchical systems and structures. Goleman (2002) suggests that the distributed view of leadershipoffers a frame for studying leadership practices including 'every person at entry level who in one way or another, acts as a leader'. As Bennett et al. (2003)notes, "distributed leadership is not something "done" by an individual "to others", rather it is an emergent property of a group or network of individuals in which group members pool their expertise'. Similarly, Spillane et al. (2001) consider distributed leadership as a form of collective agency integrating the individuals' activities at school toguide other teachers in the process of instructional change. Thus, researchers claim that sustainable school improvement ought to be empowered by leadership, which is distributed among stakeholders (Barth, 2001; Fullan, 2001; Harris, 2003; Marks \& Printy, 2003). Due to the intensification of collaborative work activities of school administrators, selected approaches to leadership should not be exclusive to principals, instead it must be sustainable for those who lead (Donaldson, 2001) since, according to Hall and Hord (2001), principals cannot do it alone. Hopkins and Jackson (2002) recommend that formal leaders of schools ought to orchestrate and nurture the space for distributed leadership to occur and create the 'shelter conditions' for the leadership of collaborative learning.

Obviously, distributed leadership definitely contributes to school improvement and createsan internal capacity for development (Harris, 2004). Glickman et al. (2001)review successful school improvement efforts and construct a composite list of the characteristics of what they term the 'improving school', a 'school that 
continues to improve student learning outcomes for all students over time'. Distributed leadership is placed on the summit of that list under the varied sources of leadership.Heck \&Hallinger(2009, p.662) defineschool improvement leadership 'as an influence process throughwhich leaders identify a direction for the school, motivate staff, and coordinatean evolving set of strategies towards improvements in teaching and learning. This emphasises our belief that the effects of school leadership arelargely mediated by academic and social conditions present in the school andaimed towards learning outcomes.'

Harris (2004) revise two studies by Day et al. (2000) and Harris and Champon (2002)regarding the relationship between distributed leadership and school improvement in which a question is raised of whether distributed leadership is 'top-down' or 'bottom-up'. Likewise, Bennett et al. (2003)consider the relationship between positional and informal leadership as a means of exploring the top-down/bottom-up dichotomy. Moreover, they look at sources of change and suggest that the thrust for developing distributed leadership can arise from a variety of influences and that it is possible that the 'development of distributed leadership . . . may be found in the shape of a "top-down" initiative from a strong or charismatic leader'. Truthfully, the literature has been less clear; however, on the exact form that this distributed leadership takes, which is evidenced in Bennett's et al. (2003)recent review of the literature on distributed leadership as'there were almost no empirical studies of distributed leadership in action'. Hence, accounts of distributed leadership in practice are not readily available and 'operational images' of distributed leadership are not forthcoming(Hopkins \& Jackson, 2002).

The theoretical framework of this study is grounded on the multifactor transformational/transactional leadership model(Bass, 1985, 1990; Bass \& Avolio, 2000). Transformational versus transactional leadership modelrecognises that no single individual could probablyoffer effective leadership and a higher level of leadership effectiveness unless others are empowered and involved in working towards common goals. Louis and Miles (1990) mention that for effective implementation of a vision, distributing power is critical. Sergiovanni (1987) document thata distributed leadership role in a school permits the principal to spotlight on a more constructive role. Burns (1978)portray transformational leadership as one or more people involving others in a manner that both the leaders and followers harmonise each other to higher levels of motivation and morality.

Bass (1990) speculate that effective leadership contains both transactional and transformational approaches which consist of six leadership characteristics, as stated by Bass and Avolio(2000). First, charismatic/inspirationalprincipals energise followers with a clear sense of purpose and build identification with their articulated vision. Second, intellectual stimulated principalsencourage followers to question the tried and true ways of solving problems and question the methods they employ to improve upon them. Third, individualised consideration principals focus on understanding the needs of each follower and work continuously to coach them in order to develop their full potential. Fourth, contingent rewarding principalsclarify what is expected from followers and what they will receive if they fulfil expected levels of performance. Furthermore, active principals-by-exception focus on monitoring task execution for any problems that might ariseas well as correcting those problems to maintain current performance levels. Finally, passive avoidant principalstend to react only after serious problems to take corrective actions and often avoid making any decisions at all. Gold et al. (2002) introduce the head teacher as a source or impetus for generating the distributed form of leadership. Similarly, Day et al.(2000) and Harris and Chapman (2002) refer to the role of the head teacher in fostering and generating distributed leadership rather than a conclusive evidence of the relationship between school improvement and distributed leadership.

Yu (2005) conduct a case study in Hong Kong Protestant Christian secondary schools to investigate the phenomenon of principal leadership. It is found out from the teachers'perceptions that principals aregenerally open, democratic, hard-working, communicating with teachers and students informally or formally. Moreover, the interaction between principals with students is described as both informal and formal in which students have the opportunity to express their needs and feelings in assemblies, circulars, and school reports. Simultaneously, the principalshows openness, democracy and support to students generally. Besides, the relation with teachers is exhibited as informal and formal via staff or committee meetings, showing trust, openness and democracy generally. The principal guidesthe decision-making process with more consultation and collaboration.Henceforth, the leadership role has changed from autonomy to shared decision making with the Deputy Principals, committees and even teachers.

A contemporary review of the literature recognised certain blank spots (i.e. shortcomings of research) and blind spots (i.e. overlooked areas) within the leadership field. The type of distributed leadership being practiced in schools represents the important blank spot that contributes to the sustained school improvement (Protheroe, 2005). On the other hand, much of the research literature has focused on the formal leadership of head teachers in particular overlooking the kinds of leadership, which can be distributed across many roles and functions in the 
school, and hence, this resembles the blind spot.Several researchers, such as Owens(2001), Rasik and Swanson (2001), and Morrison (2002) who have tended to over-rely on accounts of head teachers to define effective leadership in action, and, to a certain extent, neglected leadership at other levels or from other perspectives(Muijs \& Harris, 2003).

Consequently, theoverreaching aims of the current study are firstly, toinvestigate teachers' perceptions of the type of distributed form of leadership applied in their schools and secondly, to inspect whether the existing type of leadership contributes to school improvement.

\section{Methodology}

The current study employeda qualitative method via applying a case study approach through interviewing two in-service teachers, whowere Teaching English to Speakers of Other Languages (TESOL) at two different schools located in Pulau Penang, one of the Malaysian states. In terms of the type of school, one of the two schools was a Tamil school situated in a rural area, whilst the other one was originally founded as a religious school in an urban area; however, it has recently become a school whose only and main concern is delivering pure and mere education especially after being a governmental school. Random purposive sampling technique was followed for the purpose of selecting the study'sparticipants. Regarding the two interviewee teachers, both were senior TESOL female teachers at primary schools. One of them was the head of the English language panel at a Tamil school, whilst the otheronewas the discipline teacher ataformerly-religious and presently-pure-education school.

A semi-structured interview was utilised as the main and only instrument to get the in-depth information for the purpose of answering the two research questions. The instrument was reliable and valid based on a university lecturer. The two interviews were audio-recorded using Sony digital voice editor device and they were transcribed later to make the job of interpreting the data easier. Both interviews took about fourteen minutes each to be conducted.

The first analysis was a 'within-case analysis' searching to explore in-depth information about the applied form of leadership in each school and to identify themes within the school which was followed by the second analysis 'cross-case analysis' (Cresswell, 2003) to make a comparison and analyse the similarities and differences of the derived themes.

\section{Empirical Results}

The first interviewee describes the structure of the school as having the principal at the head of the school with 3 assistants under him and then the teachers come later followed by the students. It is a Tamil primary school in a rural area. Regarding the characteristics of the current principal in that school, the interviewee exposes very positive perceptions via utilising some positive words which are: 'very kind', 'very understanding', easy-going', 'flexible', 'approachable', 'easily get along with him', 'active', 'inspiring', 'motivates teachers', 'accepts things if they sound reasonable', 'happy to work over there' and'effective'. The interviewee explained:

What I mean by understanding, when I come up with any problem I can feel free to go and discuss things with him. It is not that I must get an appointment. There are no barriers between him and us. Even students are allowed to go and see him at any time.

(Int. 01/ F/line26-28)

Moreover, the interviewee asserts that her principal is the sort of person who solves issues logically by employing discussions especially concerning parents' complaints against teachers. The interviewee comments:

If parents complain about their child's mark against a particular teacher, he normally calls the parents to come and see him in the school and then he will call that particular teacher with the test paper because sometimes students change their answers when standing in front of their parents due to feeling scared. So if a teacher has done a mistake, he told the parents: anything regarding my teachers you should come to the school to settle things over.

(Int. 01/F/line74-79)

In terms of the form of leadership applied in the school, the interviewee elucidates that both of top-down and bottom-up distributed form of leadership exist in their school since the principal allows teachers to have the opportunity to share ideasand expertiseas well asgive suggestions and permits the students the chance of running school activities, for instance the interviewee mentioned: 
Normally, students are given the choice in the extra activities where they will be holding the post of chairperson, secretary and treasurer. They will have their committee members and then teachers will assist and guide them but running the show is the students' responsibility.

(Int. 01/ F/line16-18)

Given the voice of teachers in the school, the interviewee states that:

I'm the one who has the qualification to teach English in the school compared to other teachers. I used to teach in a secondary school before teaching in this primary school. Thus, based on my experience and qualification I was chosen as the head of the English panel so that whatever happens in the panel, the decision is mine.

(Int. 01/ F/line29-33)

However, the interviewee claims that the principal accepts their suggestions if they do not contradict the real situation by saying:

We are given the authority to decide things; yet, the final decision is his due to the autocratic power that he has. So we can give our opinions, suggestions and he will decide depending on the environment, budget and culture whether it is appropriate to the students over there since we sometimes come from outside and don't live with them. Hence, we don't know about students' parents, environment and background.

(Int. 01/ F/line05-09)

Finally, the interviewee accentuates that the form of the leadership applied in her school is the reason behind the school's improvement, which is apparentfirstly, in the students' academic achievements and secondly, the migration phenomenon of the students from the neighbouring areas to that particular school. The interviewee comments:

After he became the principal in my school, the results of the students have really gone up. At the moment, students from all over the area come to the school. Even students from neighbouring schools travel to our school because of their perception of the good results produced by our school. Thus, it hasimproved and now became one of the best ten among Tamil schools.

(Int. 01/ F/line80-83)

On the other hand, the second interviewee illustrates that the control form of leadership is the type applied in her school by commenting:

I think most of the time it is very autocratic. We do make suggestions during class meetings and all that but we rarely see the suggestions being taken up. Whatever we do in or outside the classrooms, we have to get much permission, a lot of routine work and we stick very much by the rules because we have to follow the rules.

(Int. 02/ F/line01-04)

It is declared via the interview that the principal is not an inspiring or a motivator kind of person; he even lackshaving social relations with both the teachers and students as well. Moreover, it is revealed that he has neither the charisma nor the compassion. However, he is good at paper work and school policy thatis evidenced by the interviewee's words:

I think he is not charismatic and inspiring person but he is very good at paper work and school policy. I would say he is well but not exceptionally well. He misses dealing with teachers in terms of social relations.

(Int. 02/ F/line36-38)

Not surprisingly, the control form of leadership does not contribute to the students' academic achievement and school improvement, which is exposed through the interviewee's response:

I would say that the school has deteriorated under him. Students' academic achievements have nothing to do with him but to do with us teachers especially those ones who teach exam years. Within the current type of control leadership that exists in the school, I think the school hasn't been improved.

(Int. 02/ F/line42-50)

It is also exhibited that the interviewee plays a significant role in the school after being chosen as a discipline teacher through granting students for the first time an opportunity to use their voices to vote for electing their prefects. Not only that, the teachers are also involved in the voting process for the first time as well since they have never had the autonomy to do such a thing before. Bringing new ideas to the school face some obstacles by 
the routine work via informing the concerned assistant who, on his turn, will convey the idea to the principal and discuss it with him only to be delivered to the teacher later about whether it is accepted to be executed or not. Hence, the principal only makes the decision without even consulting the particular teacher who has made the suggestion. The interviewee mentions:

It was my own idea so I did apply for permission by speaking to the students' affairs assistant and then he forwarded it to the headmaster. In the end, they all agreed because this is the first time we do such a thing so he said let's try it and see how it goes.

(Int. 02/ F/line52-54)

Furthermore, the interviewee states that she does contribute to the school through her new duty as a discipline teacher via improving the students' values and attitudes towards their school justifying her strictness by her consideration of awareness for keeping the school clean. She comments:

I found that our school used to be so dirty, the boys used to throw rubbish everywhere. There was no much consciousness until I took over this year the responsibilities of discipline teacher. I am strict but I consider awareness. The students' performance goes up regarding students' attitudes because it is not only academic but has to do with values and morals.

(Int. 02/ F/line56-59)

Finally, the interviewee declares that she supports applying the distributed form of leadership among everyone in the school by expressing:

I am with sharing leadership among the students and all staff members in the school because other teachers and I have seen different types of management styles so we think that this one is not up to our mark.

(Int. 02/ F/line60-62)

\section{Discussion}

The current case study is carried in order to answer the two research questions, which are: firstly, what are the teachers' perceptions of the type of distributed form of leadership applied in their schools?And secondly, does the existing type of leadership contribute to school improvement? Both questions were answered by interviewing two TESOL teachers from different schools following the semi-structured interview protocol. Both interviews were audio-recorded, transcribed and interpreted later. It is demonstrated that both teachers have different forms of leadership in their schools; yet, both are with distributing leadership among everyone in the school by sharing the authority. It is exhibited that both teachers have good perceptions of applying distributed form of leadership although the reality of the second interviewee's context is different regarding the existing type of leadership (i.e. the control type). In this respect, the first interviewee reveals her perception towards distributed form of leadership in the way she praises the principal's characteristics which is quite similar with Yu's findings (2005) where teachers praise their principals' characteristics as open, hard-working, democratic and having formal and informal interactions with both of students and teachers. However, the second interviewee expresses her disapproving perception towards the control form of leadership through criticising the exiting principal's characteristics.

Accordingly, the first question is answered when the first intervieweehighlights how the current form of distributed leadership contributes to their school improvement and makes it one of the best ten among Tamil schools to the extent that students from the neighbouring schools travel to their school because of the good reputation that the school has gained under this principal. On the contrary, the second interviewee complains about her school deterioration reasoning it to the type of control form of leadership applied in their school describing it as very autocratic and has not reached to their expectations as senior teachers yet. To sum up, distributed form of leadership does contribute to the school improvement as it is evidenced in the first interviewee's case, whilst the second interviewee recommends sharing leadership as a mean to raise school improvement.

\section{Recommendations for Further Studies}

Due to the fact that the current study investigates only two teachers' perceptions on distributed leadership, many more studies are required before firm conclusions can be drawn about the forms of distributed leadership activity that contribute to school improvement.A recommendation for a further study is required to be conducted investigating students' and even parents'perceptions towards the role of distributed form of leadership on school improvement.Undoubtedly, a need to be aware ofthe role of distributed leadership in action and how it can be nurtured, supported and developed should be taken into consideration. For this reason, morequalitative studies on 
distributed leadership are demanded to be carried out that interrogate the relationship between distributed leadership and school improvement. What is most crucial is to know whether distributed form of leadership doescontribute to improve students' performance and, if so, in what form. Unless distributed leadership positively affects the quality of teaching and learning, it willencourage schools to operate more openly and encourage teachers to work more collaboratively. Finally, a longitudinal research is required to be conducted to see the role of distributed leadership in school improvement over time.

\section{Summary and Concluding Remarks}

Distributed leadership has appeared to contribute to the school improvement.On the contrary, the control form of leadership often directs into school deterioration. The current study aims to investigate teachers' perceptions of the type of distributed form of leadership applied in their schools as well as inspect whether the existing type of leadership contributes to school improvement. It is worth remarking that the current study has contributed to the body of research regarding the importance of TESOL teachers' perceptions towards distributed leadership in school improvement.

\section{References}

Barth, R. (2001). Teacher leader. Phi Delta Kappan, 82(6), 443-449.

Bass, B. M. (1985). Leadership and Performance Beyond Expectations. New York, NY: Free Press.

Bass, B. M. (1990). Bass \& Stogdill's Handbook of Leadership: Theory, Research, and Managerial Applications (3rd ed.). New York, NY: Free Press.

Bass, B. M., \& Avolio, B. J. (2000). MLQ Multifactor Leadership Questionnaire: Sampler Set (2nd ed.). Redwood City, CA: Mind Garden Inc.

Bennett, N., Harvey, J. A., Wise, C., \& Woods, P. A. (2003). Distributed Leadership: A Desk Study. (8 March, 2010). [Online] Available: www.ncsl.org.uk/literature reviews

Burns, J. M. (1978). Leadership. New York NY: Harper \& Row.

Cresswell, J. W. (2003). Research Design: Qualitative, Quantitative and Mixed Methods Approaches (2nd ed.). Thosands Oaks: Sage Publications.

Day, C., Harris, A., Hadfield, M., Tolley, H., \& Beresford, J. (2000). Leading Schools in Times of Change. Milton Keynes: Open University Press.

Day, D., Gronn, P., \& Salas, S. (2006). Leadership in team-based organizations: On the threshold of a new era. The Leadership Quarterly, 17(3), 211-216. http://dx.doi.org/10.1016/j.leaqua.2006.02.001

Donaldson, G. A. (2001). Cultivating leadership in schools: Connecting people, purpose, and practice. New York: Teachers College Press.

Fullan, M. (2001). Leading in a Culture of Change. San Francisco: Jossey-Bass.

Fullan, M. (2006). The development of transformational leaders for educational decentralization. Toronto, Canada: Michael Fullan.

Glickman, C., Gordon, S., \& Ross-Gordon, J. (2001). Supervision and Instructional Leadership: A Developmental Approach. Boston, MA: Allyn \& Bacon.

Gold, A., Evans, J., Early, P., Halpin, D., \& Collabone, P. (2002). Principled Principals: Value Driven Leadership: Evidence from Ten Case Studies. Paper presented at the AERA.

Goleman, D. (2002). The New Leaders: Transforming the Art of Leadership into the Science of Results. London: Little Brown.

Gronn, P. (2000). Distributed Properties: A New Architecture for Leadership. Educational Management \& Administration, 28(3), 317-338. http://dx.doi.org/10.1177/0263211X000283006

Gronn, P. (2002). Distributed leadership as a unit of analysis. The Leadership Quarterly, 13, 423-451. http://dx.doi.org/10.1016/S1048-9843(02)00120-0

Hall, G., \& Hord, S. (2001). Implementing change: Patterns, principles, and potholes. Boston: Allyn \& Bacon.

Harris, A. (2003). Teacher leadership as distributed leadership: Heresy, fantasy or possibility? School Leadership and Management, 23(3), 313-324. http://dx.doi.org/10.1080/1363243032000112801

Harris, A. (2004). Distributed Leadership and School Improvement. Leading or Misleading?Educational Management Administration \& Leadership, 32(1), 11-24. http://dx.doi.org/10.1177/1741143204039297 
Harris, A., \& Chapman, C. (2002). Effective Leadership in Schools Facing Challenging Circumstances: National College for School Leadership.

Harris, A., \& Muijs, D. (2005). Improving Schools through Teacher Leadership. New York, USA: McGraw-Hill International.

Heck, R. H., \& Hallinger, P. (2009). Assessing the Contribution of Distributed Leadership to School Improvement and Growth in Math Achievement. American Educational Research Journal, 46(3), 659-689. http://dx.doi.org/10.3102/0002831209340042

Heck, R., \& Hallinger, P. (2005). The study of educational leadership and management: Where does the field stand today? Educational Management, Administration \& Leadership, 33(2), 229-244. http://dx.doi.org/10.1177/1741143205051055

Hopkins, D. (2001). School Improvement for Real. London: Falmer Press. http://dx.doi.org/10.4324/9780203165799

Hopkins, D., \& Jackson, D. (2002). Building the Capacity for Leading and Learning. In C. D. A. Harris, M. Hadfield, D. Hopkins, A. Hargreaves and C. Chapman (Ed.), Effective Leadership for School Improvement (pp. 84-105). London: [Online] Available: http://artofeducating.com/_library/teachers\%20and\%20leadership/Barth\%20\%20Teacher\%20Leader.pdf March, 2010).

Krüger, M., Witziers, B., \& Sleegers, P. (2007). The impact of school leadership on school level factors: Validation of a causal model. School Effectiveness and School Improvement, 18(1), 1-20. http://dx.doi.org/10.1080/09243450600797638

Leithwood, K., \& Jantzi, D. (2000). The Effects of Transformational Leadership on Organisational Conditions and Student Engagement. Journal of Educational Administration, 38(2), 112-129. http://dx.doi.org/10.1108/09578230010320064.

Leithwood, K., Louis, K. S., Anderson, S., \& Wahlsttom, K. (2004). Review of research: How leadership influences student learning. Wallace Foundation. [Online] Available: http://www.wallacefoundation.org/NR/rdonlyres/E3BCCFA5-A88B-45D3-8E27-B973732283C9/0/ (6 March 2010)

Leithwood, K., Mascall, B., \& Strauss, T. (2009). What we have learned, where we go from here. In B. M. K. Leithwood, \& T. Strauss (Ed.), Distributed leadership according to the evidence (pp. 269-282). New York: Routledge.

Louis, K. S., \& Miles, M. B. (1990). Improving the Urban High School: What Works and Why. New York, NY: Teachers College Press.

Luyten, H., Visscher, A., \& Witziers, B. (2005). School effectiveness research: From a review of the criticism to recommendations for further development. School Effectiveness and School Improvement, 16(3), 249-279. http://dx.doi.org/10.1080/09243450500114884

Marks, H., \& Printy, S. (2003). Principal leadership and school performance: An integration of transformational and instructional leadership. Educational Administration Quarterly, 39(3), 370-397. http://dx.doi.org/10.1177/0013161X03253412

Morrison, K. (2002). School Leadership and Complexity Theory. London: Routledge Falmer.

Muijs, D., \& Harris, A. (2003). Teacher Leadership: A Review of the Literature. Educational Management \& Administration, 31(4), 437-449. Available: http://www.nationalcollege.org.uk/de/media-dc8-33-teacher-leadership.pdf. (Retrieved 3rd March, 2010).

Owens, R. (2001). Organizational Behavior in Education: Instructional Leadership and School Reform. Needham Heights, MA: Allyn \& Bacon.

Protheroe, N. (2005). Leadership for School Improvement.

Rasik, T., \& Swanson, A. (2001). Fundamental Concepts of Educational Leadership. Upper Saddle River, NJ: Prentice Hall.

Reynolds, D., Teddlie, C., Hopkins, D., \& Stringfield, S. (2000). Linking school effectiveness and school improvement. In C. T. D. Reynolds (Ed.), The international handbook of school effectiveness research. London: Falmer. 
Sergiovanni, T. J. (1987). The theoretical basis for cultural leadership. In L. T. a. S. Shieve, M.B (Ed.), Yearbook of the Association for Supervision and Curriculum Development. Alexandria, VA: ASCA.

Sleegers, P., Geijsel, F., \& Van den Berg, R. (2002). Conditions fostering educational change. In K. Leithwood (Ed.), Second international handbook of educational leadership and administration. Dordrecht, the Netherlands: Kluwer Academic. http://dx.doi.org/10.1007/978-94-010-0375-9_4

Spillane, J. (2006). Distributed leadership. San Francisco: Jossey-Bass.

Spillane, J., Halverson, R., \& Diamond, J. (2001). 'Towards a Theory of Leadership Practice: A Distributed Perspective'. Northwestern University, Institute for Policy Research Working Article.

TSE, T.-H. (2006). How Teacher Leadership Leads to School Improvement: A Case Study. Paper presented at the School Improvement and University School Partnership.

West, M., Jackson, D., Harris, A., \& Hopkins, D. (2000). Leadership for School Improvement.In K. Riley \& K. Seashore Louis (Eds.) Leadership for Change (pp. 33-41). London: Routledge Falmer.

Yu, C. (2005). Principal and Teacher Perceptions of the Leadership Role of Principals in Hong Kong Protestant Christian Secondary Schools Following the Change of Sovereignty to China. Post-Script, 6(1), 1-22. [Online] Available:

http://www.edfac.unimelb.edu.au/research/resources/student_res/postscriptfiles/vol6/connie_chuen_ying_yu.pdf (12 April, 2010). 